\title{
Ethical identification of Muslim women on Mandangin Island: An ethnographic study
}

\section{Identifikasi etika perempuan Muslim di Pulau Mandangin: Sebuah studi etnografi}

\author{
Anas Ahmadi \\ Department of Indonesian Language and Literature, Faculty Languages and Arts, \\ Universitas Negeri Surabaya \\ Address: Jalan Lidah Wetan, Lakarsantri, Surabaya, East Java, Indonesia 60213 \\ E-mail: anasahmadi@unesa.ac.id
}

Article History: Received 30 September 2020; Accepted 19 January 2021; Published Online 5 February 2021

\begin{abstract}
In a community, ethics have a connection with religion. A person whose religion is vital would respect the ethics associated with that religion. Along with the current technology development, community ethics have begun to change, whether quickly or slowly. In a community, this change of ethics happens because it follows the development within modernism and globalization. This study explores the ethical identification of Muslim women in Mandangin Island, Madura Island, East Java. This study uses an ethnographic method that refers to Spradley's. Data obtained from interviews with female informants who are categorized: adolescents, mothers, and grandmothers. Based on this research data, it is known that there are three ethics of Muslim women in Mandangin Island. First, they uphold ethics, who into this group (from young to old) do not want to ride a motorbike and wear jeans that are respected on and off the island. Second, those who carry out an ethical transformation, in this group, they (teenagers) adhere to manners while on Mandangin Island; however, they ride motorbikes and wear jeans outside the island. On the one hand, those who fall into this category want to appreciate and uphold ethics in the people of Mandangin Island and want to follow modernism. They want to be able to ride motorbikes and wear jeans like most women. Third, those who violate ethics. It is most unusual for the third category because Muslim women consider themselves to adhere to religion and ethics.
\end{abstract}

Keywords: Muslim women; ethics; riding motorcycle; wearing jeans

\begin{abstract}
Abstrak
Pada suatu komunitas, etika memiliki keterkaitan dengan agama. Seseorang yang agamanya sangat penting akan menghormati etika yang terkait dengan agama itu. Seiring dengan perkembangan teknologi saat ini, etika masyarakat mulai berubah, baik secara cepat maupun lambat. Dalam suatu komunitas, perubahan etika ini terjadi karena mengikuti perkembangan modernisme dan globalisasi. Penelitian ini bertujuan untuk mengeksplorasi identifikasi etika perempuan Muslim di Pulau Mandangin, Pulau Madura, East Java. Studi ini menggunakan metode etnografi yang mengacu pada Spradley. Data diperoleh dari wawancara dengan informan perempuan yang dikategorikan: remaja, ibu, dan nenek. Berdasarkan data penelitian ini diketahui terdapat tiga etika perempuan Muslim Mandangin. Pertama, mereka yang menjunjung tinggi etika, yang termasuk dalam kelompok ini (dari yang muda sampai yang tua) tidak mau naik motor dan memakai jeans dan hal tersebut dijunjung tinggi di dalam dan di luar pulau. Kedua, mereka yang melakukan transformasi etika, dalam kelompok ini, mereka (remaja) memegang teguh tata krama selama berada di Pulau Mandangin, namun mereka mengendarai sepeda motor dan mengenakan jeans di luar pulau. Di satu sisi, mereka yang termasuk dalam kategori ini ingin mengapresiasi dan menjunjung tinggi etika dalam masyarakat Pulau Mandangin, namun juga ingin mengikuti modernisme. Mereka ingin bisa mengendarai sepeda motor dan memakai jeans seperti kebanyakan perempuan. Ketiga, mereka yang melanggar etika. Untuk kategori ketiga, hal ini paling tidak lazim karena perempuan Muslim menganggap dirinya adalah orang-orang yang menganut agama dan etika.
\end{abstract}

Kata kunci: perempuan Muslim; etika; mengendarai motor; mengenakan jeans

\section{Introduction}

In Madura Island, most people are Muslim (Kuntowijoyo 1986, de Jonge 1989a, 1989b, Rifai 2007). Similarly, the majority of Mandangin Island, which belongs to Madura Island, is also Muslim. In Mandangin Island, Islamism is led by Nahdatul Ulama (NU), which was once spearheaded by KH Hasyim Asyari, while Islamism brought by Muhammadiyah is still rare there (Ahmadi 2011, 2012). 
There are only a few who are non-Islam in Mandangin Island. They even have to go outside the island to worship since there is only a worship place for Muslims, as a mosque and surau. Mandangin Island categorizes as a small island, with approximately 17.853 inhabitants (Kelurahan Mandangin 2008). Their primary livelihood is fisherman, making the island the largest fish supplier in Madura Island, and they also work outside the island. Their education systems are available only up to senior high schools; hence they have to go outside the island to pursue higher education.

In terms of socio-cultural life, the people of Mandangin Island have an ethic related to women. Etymologically, ethic ( $\dot{\eta} \theta$ เós [Greek]) is a study related to the different concepts of good and evil, right and wrong matters (Machan 1997, Deigh 2010). In a community, ethics can still be enforced or changed, and it depends on individuals who uphold ethics. This article intends to explore the ethical changes within Muslim women in Mandangin Island and is guided by Spradley's $(1979,1980,2011)$ about ethnography, which is part of the culture.

This research used an ethics changes perspective. Historically, the term ethics emerged in the Greek period, especially during Socrates, Plato, and Aristotle. Socrates is known as a figure who gave rise to the term' virtue ethics.' Meanwhile, Plato suggested ethics as a standard of good and evil (Cavenagh 1909). After that, the term of ethics becomes more prevalent when Aristotle wrote about ethics; according to Aristotle (2000), it can be understood that each behavior has a purpose toward virtue

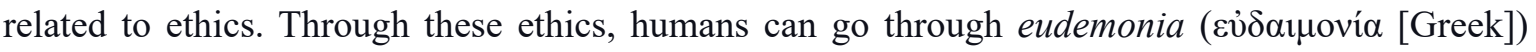
(happiness). According to Plato and Aristotle's thoughts, the essential contribution of ethics is to benefit people's lives both in an individual and communal context. Bertens (2009) said that ethics could make human becomes human. Persson \& Savulescu (2019) view that ethics is related to society's good and wrong contexts; they are also related to good and evil in yourself as a unique person. Ethics not only have a function for society; however, they ignore individual functions. Therefore, ethics must have a balance between individual functions and the functions of society. If the two are balanced, an ethical function will indeed emerge for individuals and society as a macrocosm. In this context, research directed at women's ethics, LaFollette (2020) states that women's ethics are related to feminism, which refers to the context of gender, sex, race, and people's views on women.

In a community, ethics have a connection with religion. A person whose religion is vital would respect the ethics associated with that religion. Along with the current technology development, community ethics have begun to change, whether quickly or slowly. In a community, this change of ethics happens because it follows the development within modernism and globalization. This research aims to explore the ethical identification of Muslim women ethics in Mandangin Island.

\section{Research Method}

This research used an ethnographic approach, which narrated the individual experience (the researcher) to be used as research data (Clandinin \& Connely 1994, Anderson 2006, Wall 2006, Cann \& DeMeulenaere 2012, Lapadat 2017). One of the advantages of ethnography is it is creative and integrative (Ferrandiz 2020, Hickey \& Smith 2020, Ravindran et al. 2020) in terms of exposure to research data. Windhorst (2016) also affirmed that auto-ethnography is a personal narrative. In this matter, the individual experience as research data is assumed to be a breakthrough of subjectivity and relativity 'confined,' which is supposedly not appreciated by the scientific world. The scientific world also has its close relative, pseudo. To obtain the informant data comprehensively, the researcher used Spradley's lens (1979), namely: 1) thorough enculturation, 2) current involvement, 3) an unfamiliar cultural scene, 4) adequate time, and 5) non-analytic. Besides, in order to avoid bias, the researcher also refers to Kauffman (1992), Fields (2013), and Ghosh's (2016) views that researchers must be able to position themselves as an ethnographer and must not bring up subjectivity related to malefemale relations.

In addition, the researcher also used a specific criterion in which the informants have to be female around the age of 15-65 years. The data collection was conducted for a week from May $1^{\text {st }}$ to $7^{\text {th }}$, 2018. During that period, the researcher stayed in the informant's house (HM). Based on the 
informant criteria, the data of informants found as follows: MS (teenager), SM (teenager), FH (mother), and DS (grandmother); they are native women of Mandangin Island. Qualitative data used in this research is based on the informants' interview and the researcher's observation during the data collection. Qualitative data are then interpreted according to the study's focus (Chenail 1992) to produce an analysis and interpretation of research that is relevant and can be justified theoretically, methodologically, and empirically. The research location is Mandangin Island, which included Sampang District, Madura Island, East Java. This island is also called an island village because its area is equivalent to a village. Mandangin Island only has three small villages: Candhin, Kramat, and Barat. The researchers boarded a wooden ship from Tanglog pier to the Mandangin pier to get to the location, and the journey took about 30-50 minutes.

The data analysis technique adopted a qualitative model that refers to Miles \& Huberman (2009), the identification of data that is relevant to the ethics of Muslim women seeing (the data used in the study is a transcription of the results of the interview, which translated from Madurese to Indonesian), classification of data relevant to ethics of Muslim women, reduction of data relevant to the ethics of Muslim women viewing, data exposure, and data verification. To validate the data, the researcher triangulated with peers and the Madurese language authority.

\section{Results and Discussion}

\section{Mandangin Muslim women and riding motorcycle ethics}

In this modern era, riding a motorcycle is a common thing for some people in general. For women, riding a motorcycle is a manifestation of emancipation in order to be equal with men. Moreover, women who can ride a motorcycle can be categorized as independent women because they do not need to depend on men. Women who can ride a motorcycle can go everywhere freely without asking for the help of men. It is indeed a representation of gender equality. In life, whether in a philosophical, psychological, anthropological, or religious context, there is no distinction between women and men. They have equality in various aspects of life; however, in particular cultural communities, they are sometimes related to religious issues and gender inequality (Hitman 2018). The problem does not lie in religion however instead in the dominance of men. Men control women in various aspects of life, social, political, economic, and even religious.

The ethics of riding a motorcycle is a unique phenomenon related to Mandangin Muslim women's ethics. In the Mandangin Island community, women who ride motorcycles view as having no ethics. They assume that those who ride a motorcycle are not good women in terms of ethics and religion. Hence, Muslim women are not allowed to ride a motorcycle; if they have to go to the market, beach, or school, Muslim women have to be accompanied by men as the rider. In this context, men can be husband, relative, or neighbor. Furthermore, Mandangin Muslim women also do not wear jeans. Mandangin Island's community considers the women who do so have no ethics as they resemble men if they wear them, and they believe women should not dress like men.

\section{Women upholding the ethics firmly: No riding motorcycles and no wearing jeans}

The first category is Mandangin Muslim women, who maintain the ethics rule. They are Muslim women who do not want to learn to ride a motorcycle. This situation makes them unable to ride a motorcycle and leads them to be dependent on men. Women categorized as mothers may ask for help from their husbands or sons for being their riders when they go to the market, beach, or shop. Meanwhile, teenagers are mostly accompanied by their father or brother on a motorcycle if they have to go somewhere. The grandmothers prefer to let their son, son-in-law, grandson, or husband ride the motorcycle for them. Therefore, the first category is women who cannot go out without men taking them everywhere in their daily life.

Furthermore, the first category of women is mostly conservative, including housewife mothers, traditional grandmothers, and obedient teenagers. In the Mandangin Muslim community, parents give their daughters and granddaughters advice to preserve ethics. In this matter, parents do not let them be disobedient to the ethics within the community. If they do not adhere to the local community's 
ethics, they will be ostracized for violating the ethics. Following are the results of interviews with a Muslim woman (DS), she said:

"I am delighted and comfortable if I cannot use a motorbike. A woman is indeed unethical if riding a motorcycle themselves, only men who ride motorbikes. It has always been a tradition because women are not ethical when riding a motorcycle. Also, many women now wear jeans, that also adds even more unethical."

In this context, shame will arise in women when they use vehicles. Shame is considered part of society's ethics, which is more directed to the ethics of women. A good woman's figure will have a high sense of shame when she violates society's ethics. In this context, Mcaleer (2010) explains that shame has nothing to do with ethics because ethics is more about virtue, and shame does not necessarily belong to the realm of virtue. Related to shame in an ethical context, this is also not considered an ethical setback. Someone shy should not be regarded as a skeptic and considered as being unethical (Fanselow 2011). Thus, the shame raised by Muslim women in Mandangin is not also related to ethical setbacks.

From the religious side, Muslim women who uphold ethics firmly, especially for not riding a motorcycle, are considered strongly religious women. They would simultaneously perform religious rituals, including praying five times a day, full fasting during Ramadhan, doing sunnah fasting during Rajab, post-Syyawal, and Arofah. The religious observance can also be seen from women who have gone for the hajj (they are known as hajjah); they indeed cannot ride a motorcycle. This category's women are proud and happy about not riding a motorcycle. They even disagree with the emancipation movement invested through this activity. They also explain further that this activity is an inherent obligation toward men. Hence, they view riding a motorcycle as an unethical activity both in a traditional and religious context. The following are the results of the interview with the Muslim woman informant (MS), she said:

"I want to drive, but I do not want to use a motorcycle. I do not want to learn motorbike because it is unethical for women. If a woman rides a motorcycle, she is considered to have no ethics. Men also do not like women who ride motorbikes. They prefer women who cannot ride motorbikes. That is why women do not want to ride a motorcycle."

In addition, the women of the first category also do not want to wear jeans. From their point of view, jeans are usually associated with men's fashion. Women should dress appropriately as women, not the kind of fashion resembling men. Wearing jeans pants also makes the women's body curve (especially thighs and legs) more visible, so that it may arise the men's lust. They believe that it can magnify their sins. Those classified in this group firmly uphold both important ethics when they go to college outside Mandangin Island. One of the college students in Surabaya explained that she does not want to ride a motorcycle and wear jeans even though she is not around the Mandangin Island community. She said that the location does not matter, whether she is at Mandangin Island or not; she would keep protecting her ethics as a Mandangin Muslim woman. She also added that those who betray the ethics when staying outside the island are seen as having hypocritical behavior (different between heart and action) in Islamic belief.

\section{Women transforming the ethics: Not riding motorcycles in Mandangin-riding motorcycle outside Mandangin and wearing jeans}

The second category is Mandangin Muslim women who adopt ethics. The women of this category are aware of modernism. Nevertheless, they also want to keep protecting the ethics of Mandangin Island. Most of them are teen Muslim women who take their education, either school or college, outside Mandangin Island, which leads to the changes in how they perceive the ethics of riding a motorcycle.

The ethics changes can be seen through two different situational characters when staying in and outside Mandangin Island. The second category of women does not want to ride a motorcycle when they stay in Mandangin Island. If needed, they also explain to some people that they cannot ride a 
motorcycle. For this reason, they can protect themselves from being acknowledged as an ethical woman; however, they can ride a motorcycle outside Mandangin Island. In doing so, they have to be cautious not to ride it openly. They have to keep being aware of their surroundings, whether it is an area free of Mandangin Island people or not, before finally going out with their motorcycle. They do so because they are afraid of being reported to Mandangin Island's community after being caught riding a motorcycle by people from Mandangin Island. The following are the results of the interview with a Muslim woman informant (FH), she said:

"I really do not ride a motorcycle on Mandangin Island because women who ride motorbikes are considered unethical. I do not want to be considered a woman who violates ethics. I also want to obey what my parents say that women should not ride motorbikes. If I ride a motorcycle, I am considered an unfilial child. If I want to go to the market, I asked my husband to accompany me. If there is no husband, I ask my child for help, and if no one takes me, I walk. I can go as long as I do not ride a motorcycle."

The second category of women also believe that they are not conservative people; however, they also do not want to be labeled as unethical women at the same time. It can be said that they want to be a modern woman without challenging or ignoring the ethics of Mandangin Island people. It means they can feel less guilty about violating ethics.

In terms of wearing jeans, the second category of women also has some changes. The same as riding a motorcycle, they are also afraid of being judged as unethical if they wear jeans while staying on the island. They prefer to wear them only when living outside the island since there are no Mandangin Island people. Moreover, they also argue that jeans are a symbol of freedom. If men can wear jeans freely, women also have the right to do the same. In this context, women are hegemony by male power (Susanti 2018). Therefore, they (women) assume that everything related to ethics cannot be separated from men's view. Not all ethics are related to male power, and it is called gender inequality.

\section{The factors behind the ethical changes in Mandangin Muslim women}

Various factors cause ethical changes in Mandangin Muslim women. First, it is related to the socioanthropological context. While living outside the Island, Mandangin Muslim women can meet those who live in urban areas. They see that urban women's lifestyles require them to be more independent when they have somewhere to go, such as going to college, a shopping center, a bookshop, or a library. They have to ride a motorcycle to have easy access to reach a study or shopping place. Recently, the contemporary lifestyle urges teenagers to have a minimum of one new motorcycle. Consequently, the average college student may have a motorcycle. It is the reason why Mandangin women also want to ride motorcycles.

Another case concerns jeans, and urban women wear them because of their simplicity, effectiveness, and elegant look. They also argue that jeans can show equality between women and men. As for those who do not wear jeans, they believe that they would be affected over time by an urban friend who wears jeans daily. Following are the results of an interview with a Muslim woman (SM), she said:

"Today, we cannot refuse modernization. Women have gender equality. They (women) have equality with men in various fields. Especially in terms of culture. If a man can ride a motorcycle, women may also ride a motorcycle. That is culture. In culture, there should not be an imbalance between men and women. I do not dare to say that I support ethical change in Mandangin Muslim women; however, I want a better chance. It relates to gender equality, not to ethics."

In this matter, it can be said that several factors are causing the ethical changes within the Muslim community in Mandangin Island. The first is about their modern way of thinking. Those who take their education outside the island tend to be less aware of the ethics applied in Mandangin Island, which they assume to be outdated. The second is the influence of modernism, which has affected the island through the rise of smartphones. The use of smartphones can help them access the internet 
easily so that the Mandangin Island community can easily access various segments. This rise of modernism is also the reason why the ethics changes happen in the Mandangin Island community.

The second factor concerns the psychological context. Humans essentially have a desire for xenophilia (willingness to try something new-unfamiliar). Mandangin women are influenced psychologically by their urban friends who ride motorcycles daily. If their social life circle, they are not allowed to ride a motorcycle. So, Mandangin women choose to have 'two-faces.' They certainly follow the ethics on Mandangin Island; however then violate them outside the island.

The change in ethics of Mandangin Muslim women is related to looking, and way of life in society and is indeed unstoppable. Changes in various social life segments, culture, and religion are inevitable along with the era of globalization and modernization, which demands changes in various fields. Therefore, ethics also change as a result of globalization and the modernization of society. Changes in ethical Muslim Mandangin women is not a bad thing and not a wrong thing. In Linn's view (2019), ethics indeed cannot be made right and wrong about modern society. Ethics and virtue are human ideals and the hope to be useful in community life; however, this is an idealism that is difficult to achieve by the community. The ideals and hopes about ethics found in society will last forever; however, they will always change from time to time. In addition to the two categories, namely Muslim women who observe ethics and women who want to carry out the ethical transformation, some Muslim women are seen as violating ethics. Concerning riding motorbikes and wearing jeans, women who violate these ethics are scolded by their parents. It is because parents are considered unable to teach ethics to their children. In addition, women who violate ethics (riding motorbikes or wearing jeans) will be shunned by local men because they are considered unethical.

\section{Conclusion}

Mandangin is a small island, like a remote island, life ethics are still firmly held by its supporting community. The Mandangin woman, as a robust ethical holder on Mandangin Island, shows and proves this. Based on those explanations, it can be concluded that Mandangin Muslim women's ethics are divided into three categories. First is women upholding the ethics indeed in which they decline to ride a motorcycle and wear jeans (either young or old) and who would choose to maintain these ethics both in and outside the island. The second is women transforming the ethics, in which most of them are teenagers who obey the ethics regarding both riding a motorcycle and wearing jeans in Mandangin Island; however, they violate both ethics outside the island. On the other hand, they precisely want to uphold and respect the Mandangin Island community; however, they also want to follow modernism. In the end, they want to ride a motorcycle and wear jeans like women in general. Third are the Mandangin Muslim women who violate ethics. It is the least common for the third category because Muslim women believe themselves to adhere to religion and ethics.

\section{References}

Aristotle (2000) Aristotle: Nicomachean Ethics. New York: Cambridge University Press.

Ahmadi A (2011) Menyusur Mandangin. Surabaya: Akademos.

Ahmadi A (2012) Budaya Masyarakat Kepulauan. Surabaya: Unesa Press.

Anderson L (2006) Analytic autoethnography. Journal of Contemporary Ethnography 35 (4):373395. https://doi.org/10.1177/0891241605280449.

Bertens K (2009) Perspektif Etika Baru: 55 Esai tentang Masalah Aktual. Jakarta: Kanisius.

Cann CN \& DeMeulenaere EJ (2012) Critical co-constructed autoethnography. Cultural Studies $\leftrightarrow$ Critical Methodologies 12 (2):146-158. https://doi.org/10.1177/1532708611435214.

Cavenagh F (1909) The Ethical End of Plato's Theory of Ideas. London: Price Two Publishers.

Chenail RJ (1992) Qualitative research: Central tendencies and ranges. The Qualitative Report 1 (4):1-3. https://doi.org/10.46743/2160-3715/1992.2037.

Clandinin DJ \& Connely FM (1994) Personal Experience Methods. In: Norman KD \& Yvonna SL (eds). The SAGE Handbook of Qualitative Research. London: Sage. 
Deigh J (2010) An Introduction to Ethics. Cambridge: Cambridge University Press.

De Jonge H (1989a) Madura dalam Empat Zaman: Pedagang, Perkembangan Ekonomi, dan Islam, Studi Antropologi Ekonomi. Jakarta: Rajawali Press.

De Jonge H (1989b) Perkembangan Ekonomi dan Islamisasi di Madura. In: Huub de J (ed). Agama, Kebudayaan, dan Ekonomi: Studi-Studi Interdisipliner tentang Masyarakat Madura. Jakarta: Rajawali Press.

Fanselow R (2011) Self-evidence and disagreement in ethics. Journal of Ethics \& Social Philosophy 5 (3):1-16. https://doi.org/10.26556/jesp.v5i3.56.

Fields J (2013) Feminist ethnography: Critique, conflict, and ambivalent observance. Journal of Contemporary Ethnography 42 (4):492-500. https://doi.org/10.1177/0891241613483567.

Ferrandiz F (2020) Contemporary Ethnographies: Moorings, Methods, and Keys for the Future. London: Routledge.

Ghosh ST (2016) Feminist Ethnography. In: Nancy AN (ed). The Wiley Blackwell Encyclopedia of Gender and Sexuality Studies. New York: Wiley Blackwell.

Hickey A \& Smith C (2020) Working the aporia: Ethnography, embodiment and the ethnographic self. Qualitative Research 20 (6):819-836. https://doi.org/10.1177/1468794120906012.

Hitman G (2018) Arab spring era: Winds of change in the direction of gender equality for Tunisian women. Digest of Middle East Studies 27 (2):168-184. https://doi.org/10.1111/dome.12137.

LaFollette H (2020) Ethics in Practice: An Anthology. London: Wiley.

Lapadat JC (2017) Ethics in autoethnography and collaborative autoethnography. Qualitative Inquiry 23 (8):589-603. https://doi.org/10.1177/1077800417704462.

Linn M (2019) Aristotle and the globalism objection to virtue ethics. The Journal of Ethics 23 (1):5576. https://doi.org/10.1007/s10892-019-09281-7.

Kauffman BJ (1992) Feminist facts: Interview strategies and political subjects in ethnography. Communication Theory 2 (3):187-206. https://doi.org/10.1111/j.1468-2885.1992.tb00038.x.

Kelurahan Mandangin (2008) Monograf Desa Mandangin. Mandangin: Kelurahan Mandangin.

Kuntowijoyo (1986) Agama Islam dan Politik Gerakan-gerakan Syarekat Islam di Madura. In: Huub de J (ed). Agama, Kebudayaan, dan Ekonomi: Studi-Studi Interdisipliner tentang Masyarakat Madura. Jakarta: Rajawali Press.

Machan TR (1997) A Primer on Ethics. London: University of Oklahoma Press.

Mcaleer S (2010) Four solutions to the alleged incompleteness of virtue ethics. Journal of Ethics \& Social Philosophy 4 (3):1-20. https://doi.org/10.26556/jesp.v4i3.44.

Miles MB \& Huberman MA (2009) Qualitative Data Analysis: An Expanded Sourcebook. Thousand Oaks: SAGE Publications.

Persson I \& Savulescu J (2019) The meaning of life, equality and eternity. The Journal of Ethics 23 (2019):223-238. https://doi.org/10.1007/s10892-019-09296-0.

Ravindran A, Li J, \& Marshall S (2020) Learning ethnography through doing ethnography: Two student - researchers' insights. International Journal of Qualitative Methods 19 (2020):1-11. https://doi.org/10.1177/1609406920951295.

Rifai MA (2007) Manusia Madura. Yogyakarta: Pilar Media.

Spradley JP (1979) The Ethnographic Interview. New York: Holt, Rinehart and Winston.

Spradley JP (1980) Participant Observations. New York: Holt, Rinehart and Winston.

Spradley JP (2011) Ethnography and Culture. In: James WS \& David WM (eds). Conformity and Conflict: Readings in Cultural and Anthropology. Pearson: Boston.

Susanti E (2018) Unequal gender relations in the practices of girl marriage in poor families at East Java Province. Masyarakat, Kebudayaan dan Politik 31 (4):440-450. https://doi.org/10.20473/ mkp.V31I42018.440-450.

Wall S (2006) An autoethnography on learning about autoethnography. International Journal of Qualitative Methods 5 (2):146-160. https://doi.org/10.1177/160940690600500205.

Windhorst E (2016) Re-Membering ecological self: A personal narrative autoethnography. Ecopsychology 8 (4):246-270. https://doi.org/10.1089/eco.2016.0014. 